\title{
The impact of visiting operational departments on improving public health students' learning about Rabies preventions, coetaneous Leishmaniasis, and serological tests of Brucellosis: a learning trip
}

Abdurrahman Charkazi ( $\sim$ rcharkazi@yahoo.com )

Assistant Professor, PhD of Health Education and Promotion, Education Development Center, Golestan University of Medical Sciences, Gorgan, Iran

\section{Research Article}

Keywords: public health, contagious disease, learning trip, student

Posted Date: April 5th, 2021

DOl: https://doi.org/10.21203/rs.3.rs-346655/v1

License: (1) (7) This work is licensed under a Creative Commons Attribution 4.0 International License. Read Full License 


\section{Abstract}

Background: Conventional teaching through lectures cannot be of much use and efficiency for achieving the educational goals of this course. Designing community-based teachings could be influential in students' learning quality. Hence, the present study was conducted aiming to evaluate the impact of visiting the operational departments of Gonbad-e Kavous county healthcare center on improving public health students' learning of educational objectives of the national infections disease combat program.

Methods: Over a cross-sectional study, 97 students of continues and discontinuous bachelor's majoring in public health visited the department of rabies prevention and control, coetaneous Leishmaniasis(CL) control, and the central laboratory of Gonbad-e Kavous county healthcare center over the first semester of the 2017-19 academic year. These students were introduced to the methods of treating Leishmaniasis patients and those bitten by animals as well as brucellosis diagnosis tests. The students were provided with the study's questionnaire after the visit so that they could fill it in. collected data entered SPSS v. 15 statistical software and were analyzed using descriptive statistics and an independent t-test.

Results: 61 (62.9\%) of the students were female and 50 (51.5\%) people were discontinuous bachelor's students. The average satisfaction of students with the $\mathrm{CL}$, rabies control and prevention, and Brucellosis test departments was $93.38 \%, 89.25 \%$, and $82.69 \%$, respectively. Besides, the total satisfaction of the mentioned visits was $92.61 \%$. Discontinuous bachelor's students' satisfaction with rabies control and prevention and Brucellosis departments was significantly higher compared to continuous bachelor's students $(P<0.05)$.

Conclusion: results indicated that students' satisfaction with visiting the operational departments of Gonbad-e Kavous county healthcare center was high. Hence, further such visits are recommended for other public health students.

\section{Background}

Prevention and control of common and endemic diseases in an area are among the significant components of basic healthcare. Despite the considerable improvements in fighting contagious diseases, the type of treating such diseases conforming to the geographical and regional characteristics is still considered among the most imperative responsibilities of every country's healthcare system, so that every country has a distinct approach to the system of contagious disease care system according to the World Health Organization's recommendations despite the same practical and scientific medical resources [1] .

Public health discipline is an essential branch of health sciences, whose purpose is to educate and train labor forces that are aware of the needs of individuals, households, communities, and the environment. Graduates of this discipline also intervene based on their evaluation of health-threatening factors aiming to improve the level of the individual, household, and community health [2]. Given that health services in Iran are provided in an integrated way, this discipline's graduates must have the required capabilities and information in their respective areas [3]. Therefore, providing sufficient and appropriate training for this 
discipline's students is imperative and essential to accomplish the educational goals responding to the needs of society.

The national infectious disease combat program course is among the core courses of public health discipline and has a value of two credits. The objective of this course is acquaintance with the important disease for which the Ministry of Health and Medical Education has developed and executed a nationallevel program. Students must get to know the practical ways of fighting these diseases, and get acquainted with the practical and theoretical ways of controlling, fighting, and eradicating contagious diseases, and carry out their assigned tasks according to the Ministry of Health and Medical Education's program [4] . Conventional teaching through lectures cannot be of much use and efficiency for achieving the educational goals of this course. Therefore, the need for more effective teaching methods for the topics of this course is evident. One of these teaching methods is learning in the community, which results in increased interest and comprehensive and long-term learning of the factors affecting the community's health issues compared to conventional teaching. Therefore, community-based teaching could result in higher teaching effectiveness in addition to diversity in learning[5,6]. On the other hand, this type of teaching emphasized students' learning based on problem-solving skills and creative thinking [7]. Teaching within the community confirms constructivism. Using original techniques is one of the significant implications of constructivism. Original assignments are learning situations similar to or consisting of real-life situations outside the school, which means they are real and objective rather than symbolic and abstract [8].

Given the existing situation of the country in terms of the burden of diseases, population pyramid changes, cultural and social issues, etc., the necessity of change in medical education is more obvious than ever. In this regard, medical education transformation and innovation packages prepared in 2015 have laid a clear path before the respective institutions. In this regard, the justice-oriented and responsive teaching package is one of the medical education transformation packages aiming to institutionalize the approach of responsive education in the healthcare system, promote justice in healthcare higher education, network in the healthcare higher education system, and improve the human resources of healthcare higher education system. The implementation of this package is expected to adjust the higher education programs in the field of health to the community's need for this field's services, provide a suitable context for students with various cultural, social, and scientific capabilities to grow and flourish, and train labor forces responding to the needs of the community. This package is focused on revision and development of educational curricula in response to the needs of the society, diagnosis and treatment technologies, and knowledge frontiers (scientific authority) divided by medical sciences' disciplines and degrees to encourage motivation and sensitivity in students, professors, policy-makers, and service providers toward a better response to the needs of the community[9].

Located in the north of Iran, Golestan province is characterized by its geographical, climatic, and ecological diversity as well as the movement of population within and outside of it, and is witness to common and endemic contagious diseases such as animal bites, $\mathrm{CL}$, and Brucellosis. $\mathrm{CL}$ and some cases of visceral Leishmaniasis have long existed in north and north-eastern areas of the province around Maraveh Tappeh and Gonbad-e Kavous counties as a prevalent and endemic disease [10]. 
The three diseases of rabies, $\mathrm{CL}$, and Brucellosis are among the topics of the national infections disease combat program course for public health students. Hence, $\mathrm{CL}$ treatments such as cryotherapy and topical and systematic treatments are performed in the Leishmaniasis department of Gonbad-e-Kavous county healthcare center, preventive measures such as washing the wound and rabies prevention serum and vaccination are provided around the clock, and serologic Brucellosis tests are conducted consistently in the serology laboratory of the said center on the other hand.

This course used to be taught conventionally in college classrooms over the previous periods. Hence, the teacher decided to take advantage of learning environments such as the operational departments of healthcare centers in teaching the course. Therefore, the respective topics of visiting the operational departments of Gonbad-e Kavous healthcare centers were designed and implemented to achieve the educational goals of the course.

\section{Methods}

In this cross-sectional study, 97 students of continuous and discontinuous bachelor's majoring in public health who had enrolled in the national infectious disease combat program course over 2017-18 to 2019-20 academic years entered the study through consensus.

\section{Measures}

The study's data collection tool was a questionnaire of satisfaction with educational objectives' accomplishments consisting of 23 questions on a 7-point Likert scale (ranging from strongly agree to strongly disagree) containing nine questions about the Leishmaniasis unit, nine questions about the Rabies prevention unit, and five questions about the Brucellosis serological department. The students completed the questionnaire and ranked the items with scores of one to seven after the visit.

The questionnaire was designed by the teacher of the course and based on the curriculum, and was handed out to three faculty members to determine its validity; the required modification was then made according to faculty members' opinions. The questionnaire's reliability was measured through Cronbach's alpha, which was calculated to be 0.899 for the whole questionnaire, 0.843 for the Leishmaniasis section, 0.407 for the rabies prevention section, and 0.841 for the Brucellosis serology laboratory.

One question was considered to measure the overall satisfaction of each of the departments on a scale from zero to 100. In the end, one question measured the overall satisfaction of the whole visit on a scale from zero to 100 . Also, one open question was considered to ask about other suggested diseases and treatment departments relevant to the course topics.

\section{Procedure}

The teacher first referred to Gonbad-e Kavous healthcare center and got familiarized with the procedures and measures taken in the center, expressing the educational requirements and expectations. Afterward, the aforementioned departments expressed their preparedness to host the students, and correspondence with 
the Vice Chancellor for Education was done to send the students on the visit. After acquiring the required permits and confirming visit dates (November 2017 to 2019), the students were sent on a visit to Gonbad-e Kavous healthcare center. The visits were made so that the continuous bachelor's students visited the center over one week and the discontinuous bachelor's students visited it the next week. November was selected as the time for visits since it was the CL high season in Gonbad-e Kavous when patients would frequently refer to the healthcare center to treat their Leishmaniasis wounds. The students had received conventional learning material on CL, Rabies, and Brucellosis a couple of weeks before the field visits.

The order of visiting from the operational departments was so that the students would first visit the Leishmaniasis department, then the rabies prevention department, and finally, then the serological Brucellosis laboratory. During the Leishmaniasis department visits, the students watched how cryotherapy was performed and patients were treated, and learned about intramuscular and local injections and as well as the indications of each of these three treatment methods from the head of the department, and asked their respective questions. In the Leishmaniasis department, the students were divided into 5-7-people groups and watched the process of patient treatment in order. Then, the students went to the woundsampling room and got acquainted with the process of taking samples from the Leishmaniasis wound, staining the sample, and obtaining test results. Afterward, they went to the department laboratory and observed slides of $\mathrm{CL}$ under microscopes, receiving explanations and training from the laboratory expert (Master of Parasitology) working in the department. The students finally learned about the process of recording, treatment follow-up, and completing the forms submitted by the respective ministry from the head of the Leishmaniasis department.

Afterward, the students referred to the rabies prevention unit and received explanations regarding how to wash the bite wound, serum and vaccine indications, vaccination sessions, following-up on the animal, how to determine the rabies serum dose, and how to inject it. Besides, the students visited the refrigerators containing rabies vaccines and antidote serum, and the first, second, or third vaccination of animal-bitten patients referring to the health center was delivered by the respective head of the unit in the presence of students. Besides, considering the heavy load of patients referring to the center, rabies wounds were washed by the respective department head in the direct presence of students after training the students regarding the standard safety precautions for washing the wound such as wearing gloves and glasses and how long the wound must be washed. Afterward, the respective department head gave explanations on how to fill in the animal bite form, the office book, and the computer software, and explained the process of following up on the patients and the necessity of 24-hour services in the said department. Eventually, the students had a Question and answer session with the respective head and got their answers. All the students visited this department in one group considering the suitable environment of the department.

Finally, a visit to the serology department of the healthcare center laboratory took place. The visiting students were divided into two groups in this department. Wright's tube and slide tests were conducted by the respective department head in the presence of the students, and the dilatation method for changing the dilution from $1 / 20$ to $1 / 1280$ was practiced. Eventually, the students observed and read a positive serum sample infected with Brucellosis. Also, Coombs Wright's indications were explained. In the end, the students had a question and answer session with the respective head and got their answers. It must be mentioned 
that positive serological Brucellosis samples were stored in the laboratory a couple of days ahead of the visit so that they could be presented to the students.

The teacher stayed with the students throughout all operational visits to provide them with suitable educational situations and offer them the required guidance to achieve the educational objectives. After the visits, a questionnaire measuring the students' attitude toward the visit was handed out to them so that they could express their opinions. The anonymity of the questionnaire, confidentiality, and other ethical considerations such as personal consent were respected in completing the questionnaires. The general parts of this plan were approved by the Golestan University of Medical Sciences ethics committee under the number IR.GOUMS.REC.1396.236.

Analysis

Completed questionnaires were entered into the statistical software v.15, and descriptive statistics (mean, frequency, standard deviation, etc.), as well as independent t-test, were used to compare the average scores of continuous and discontinuous bachelor's students. A significance level of 0.05 was considered for all tests.

\section{Results}

97 students participated in the study and visited the aforementioned operational centers, among which 61 participants $(62.9 \%)$ were female and 50 participants $(51.5 \%)$ were male discontinuous bachelor's students, while 47 participants were continuous bachelor's students. The range of average grade scores of the students was 13.37-18.24 with an average and standard deviation of $15.91 \pm 1.04$. Results indicated that the majority of the students considered the visit to the aforementioned operational departments to be quite educative and useful to accomplish the educational objectives (Table 1).

\section{Table 1: Frequency distribution of student's view on visiting Leishmaniasis unit}




\begin{tabular}{|c|c|c|c|c|c|c|c|c|c|}
\hline \multirow{2}{*}{$\begin{array}{l}\begin{array}{l}\text { strongly } \\
\text { disagree }\end{array} \\
n \\
\%\end{array}$} & \multicolumn{2}{|c|}{$\begin{array}{l}\text { somewhat } \\
\text { disagree }\end{array}$} & \multirow{2}{*}{$\begin{array}{l}\text { slightly } \\
\text { disagree } \\
n \\
\%\end{array}$} & \multicolumn{2}{|c|}{ Undecided } & \multirow{2}{*}{$\begin{array}{l}\text { slightly } \\
\text { agree } \\
n \\
\%\end{array}$} & $\begin{array}{l}\text { somewhat } \\
\text { agree }\end{array}$ & \multirow{2}{*}{$\begin{array}{l}\text { strongly } \\
\text { agree } \\
n \\
\%\end{array}$} & \multirow[t]{2}{*}{ Item } \\
\hline & n & $\%$ & & $\mathrm{n}$ & $\%$ & & n $\%$ & & \\
\hline $0(0)$ & $0(0)$ & & $0(0)$ & $0(0)$ & & $0(0)$ & $8(8.2)$ & $\begin{array}{l}89 \\
(91.8)\end{array}$ & $\begin{array}{l}\text { Seeing the } \\
\text { Lieshmaniosis } \\
\text { wound up close } \\
\text { was very } \\
\text { helpful and } \\
\text { instructive for } \\
\text { me }\end{array}$ \\
\hline $0(0)$ & $1(1)$ & & $0(0)$ & $1(1)$ & & $0(0)$ & $6(6.2)$ & $\begin{array}{l}89 \\
(91.8)\end{array}$ & $\begin{array}{l}\text { To see how } \\
\text { cryotherapy is } \\
\text { performed on } \\
\text { patients up } \\
\text { close was very } \\
\text { helpful and } \\
\text { instructive for } \\
\text { me }\end{array}$ \\
\hline $0(0)$ & $0(0)$ & & $0(0)$ & $1(1)$ & & $2(2.1)$ & $11(11.3)$ & $\begin{array}{l}83 \\
(85.6)\end{array}$ & $\begin{array}{l}\text { It was very } \\
\text { helpful and } \\
\text { instructive for } \\
\text { me to see the } \\
\text { topical } \\
\text { treatment and } \\
\text { its indications } \\
\text { for } \\
\text { Leishmaniasis }\end{array}$ \\
\hline $0(0)$ & $0(0)$ & & $0(0)$ & $3(3.2)$ & & $1(1)$ & $9(9.3)$ & $\begin{array}{l}84 \\
(86.5)\end{array}$ & $\begin{array}{l}\text { Seeing up close } \\
\text { how the } \\
\text { systemic } \\
\text { treatment of } \\
\text { patients is } \\
\text { performed with } \\
\text { Glucantime } \\
\text { injection and } \\
\text { knowing its } \\
\text { indications was } \\
\text { very helpful and } \\
\text { instructive for } \\
\text { me. }\end{array}$ \\
\hline $0(0)$ & $0(0)$ & & $0(0)$ & $6(6.2)$ & & $2(2.1)$ & 10 (10.3) & $\begin{array}{l}79 \\
(81.4)\end{array}$ & $\begin{array}{l}\text { It was very } \\
\text { helpful and } \\
\text { instructive for } \\
\text { me to see how } \\
\text { biopsy of a } \\
\text { suspected } \\
\text { Leishmaniasis } \\
\text { wound is } \\
\text { performed }\end{array}$ \\
\hline $0(0)$ & $0(0)$ & & $1(1)$ & $4(4.1)$ & & $2(2.1)$ & $22(22.7)$ & $\begin{array}{l}68 \\
(70.1)\end{array}$ & $\begin{array}{l}\text { Seeing a slide } \\
\text { containing the } \\
\text { Lieshman body }\end{array}$ \\
\hline
\end{tabular}




\begin{tabular}{|c|c|c|c|c|c|c|c|}
\hline & & & & & & & $\begin{array}{l}\text { under a } \\
\text { microscope and } \\
\text { the } \\
\text { explanations of } \\
\text { a laboratory } \\
\text { expert in the } \\
\text { Leishmaniasis } \\
\text { unit was very } \\
\text { helpful and } \\
\text { instructive for } \\
\text { me. }\end{array}$ \\
\hline $0(0)$ & $0(0)$ & $0(0)$ & $4(4.1)$ & $4(4.1)$ & 18 (18.6) & $\begin{array}{l}71 \\
(73.2)\end{array}$ & $\begin{array}{l}\text { Observing the } \\
\text { process of } \\
\text { registering and } \\
\text { following up } \\
\text { patients on the } \\
\text { forms sent by } \\
\text { the Ministry of } \\
\text { Health and the } \\
\text { explanations of } \\
\text { the treatment } \\
\text { expert of the } \\
\text { Leishmaniasis } \\
\text { unit was very } \\
\text { helpful and } \\
\text { instructive for } \\
\text { me. }\end{array}$ \\
\hline $1(1)$ & $0(0)$ & $1(1)$ & $1(1)$ & $3(3.1)$ & $23(23.7)$ & $\begin{array}{l}68 \\
(70.1)\end{array}$ & $\begin{array}{l}\text { Epidemiological } \\
\text { interviews with } \\
\text { Leishmaniasis } \\
\text { patients and } \\
\text { their } \\
\text { companions } \\
\text { were very } \\
\text { helpful and } \\
\text { informative for } \\
\text { me. }\end{array}$ \\
\hline $1(1)$ & $0(0)$ & $0(0)$ & $2(2.1)$ & $1(1)$ & $11(11.3)$ & $\begin{array}{l}82 \\
(84.5)\end{array}$ & $\begin{array}{l}\text { The } \\
\text { explanations of } \\
\text { the treatment } \\
\text { expert of the } \\
\text { Leishmania } \\
\text { unit and the } \\
\text { transfer of his } \\
\text { educational } \\
\text { experience were } \\
\text { very helpful and } \\
\text { instructive for } \\
\text { me. }\end{array}$ \\
\hline
\end{tabular}

Besides, the majority of the students considered the visit to the rabies prevention and control department to be quite educative and useful to accomplish the educational objectives (Table 2). 


\section{Table 2: Frequency distribution of student's view on visiting rabies unit}




\begin{tabular}{|c|c|c|c|c|c|c|c|c|}
\hline \multirow{2}{*}{$\begin{array}{l}\text { strongly } \\
\text { disagree } \\
\mathrm{n} \\
\%\end{array}$} & \multicolumn{2}{|c|}{$\begin{array}{l}\text { somewhat } \\
\text { disagree }\end{array}$} & \multirow{2}{*}{$\begin{array}{l}\text { slightly } \\
\text { disagree } \\
\mathrm{n} \\
\%\end{array}$} & Undecided & \multirow{2}{*}{$\begin{array}{l}\text { slightly } \\
\text { agree } \\
\mathrm{n}_{\%}\end{array}$} & $\begin{array}{l}\text { somewhat } \\
\text { agree }\end{array}$ & \multirow{2}{*}{$\begin{array}{l}\text { strongly } \\
\text { agree } \\
n \\
\%\end{array}$} & \multirow[t]{2}{*}{ Item } \\
\hline & $\mathrm{n}$ & $\%$ & & $\%$ & & $\%$ & & \\
\hline $0(0)$ & $0(0)$ & & $0(0)$ & $2(2.1)$ & $0(0)$ & 13 (13.4) & $\begin{array}{l}82 \\
(84.5)\end{array}$ & $\begin{array}{l}\text { It was very } \\
\text { helpful and } \\
\text { instructive for } \\
\text { me to see a } \\
\text { patient who } \\
\text { was bitten by } \\
\text { an animal up } \\
\text { close who had } \\
\text { come for the } \\
\text { rabies vaccine. }\end{array}$ \\
\hline $1(1)$ & $1(1)$ & & $1(1)$ & $18(18.6)$ & $5(5.2)$ & 15 (15.5) & $\begin{array}{l}56 \\
(57.7)\end{array}$ & $\begin{array}{l}\text { Seeing how to } \\
\text { wash the bitten } \\
\text { wound and } \\
\text { hearing the } \\
\text { explanation of } \\
\text { the relevant } \\
\text { expert during } \\
\text { washing was } \\
\text { very helpful and } \\
\text { instructive for } \\
\text { me }\end{array}$ \\
\hline $0(0)$ & $0(0)$ & & $1(1)$ & $1(1)$ & $3(3.1)$ & $17(17.5)$ & $\begin{array}{l}75 \\
(77.3)\end{array}$ & $\begin{array}{l}\text { The transfer of } \\
\text { experiences } \\
\text { from an expert } \\
\text { in rabies } \\
\text { prevention } \\
\text { department } \\
\text { about the } \\
\text { indications of } \\
\text { serum injection } \\
\text { in bitten people } \\
\text { was very } \\
\text { helpful and } \\
\text { instructive for } \\
\text { me. }\end{array}$ \\
\hline $0(0)$ & $0(0)$ & & $0(0)$ & $2(2.1)$ & $1(1)$ & $9(9.3)$ & $\begin{array}{l}85 \\
(87.2)\end{array}$ & $\begin{array}{l}\text { The transfer of } \\
\text { experiences } \\
\text { and } \\
\text { explanations } \\
\text { from the rabies } \\
\text { prevention } \\
\text { expert about } \\
\text { how to follow } \\
\text { the biting } \\
\text { animals and } \\
\text { the number of } \\
\text { vaccination } \\
\text { sessions that is } \\
\text { needed was } \\
\text { very helpful and } \\
\text { instructive for } \\
\text { me. }\end{array}$ \\
\hline
\end{tabular}




\begin{tabular}{|c|c|c|c|c|c|c|c|}
\hline $0(0)$ & $0(0)$ & $0(0)$ & $2(2.1)$ & $7(7.2)$ & $20(20.6)$ & $\begin{array}{l}68 \\
(70.1)\end{array}$ & $\begin{array}{l}\text { It was very } \\
\text { helpful and } \\
\text { instructive for } \\
\text { me to see the } \\
\text { refrigerator } \\
\text { containing the } \\
\text { serum and } \\
\text { vaccine and } \\
\text { how they are } \\
\text { stored. }\end{array}$ \\
\hline $0(0)$ & $0(0)$ & $0(0)$ & $4(4.1)$ & $\begin{array}{l}13 \\
(13.4)\end{array}$ & $24(24.7)$ & $\begin{array}{l}56 \\
(57.7)\end{array}$ & $\begin{array}{l}\text { It was very } \\
\text { helpful and } \\
\text { instructive for } \\
\text { me to see how } \\
\text { to complete the } \\
\text { software for } \\
\text { registering } \\
\text { animal bitten } \\
\text { patients and } \\
\text { how to fill the } \\
\text { relevant forms } \\
\text { according to } \\
\text { the national } \\
\text { instructions of } \\
\text { the Ministry of } \\
\text { Health. }\end{array}$ \\
\hline $0(0)$ & $0(0)$ & $1(1)$ & $2(2.1)$ & $2(2.1)$ & $9(9.3)$ & $\begin{array}{l}83 \\
(85.6)\end{array}$ & $\begin{array}{l}\text { The } \\
\text { explanations of } \\
\text { the expert of } \\
\text { Rabies } \\
\text { prevention unit } \\
\text { about } \\
\text { educating } \\
\text { patients to } \\
\text { receive the next } \\
\text { dose of vaccine } \\
\text { and the } \\
\text { consequences } \\
\text { of not visiting } \\
\text { and following } \\
\text { up on patients } \\
\text { were very } \\
\text { helpful and } \\
\text { instructive for } \\
\text { me. }\end{array}$ \\
\hline $0(0)$ & $0(0)$ & $0(0)$ & $4(4.1)$ & $9(9.3)$ & 19 (19.6) & $65(6.7)$ & $\begin{array}{l}\text { Epidemiological } \\
\text { interviews with } \\
\text { Rabies patients } \\
\text { and their } \\
\text { companions } \\
\text { were very } \\
\text { helpful and } \\
\text { instructive for } \\
\text { me. }\end{array}$ \\
\hline $0(0)$ & $0(0)$ & $0(0)$ & $4(4.1)$ & $4(4.1)$ & $14(14.4)$ & $\begin{array}{l}75 \\
(77.3)\end{array}$ & $\begin{array}{l}\text { The } \\
\text { explanation }\end{array}$ \\
\hline
\end{tabular}


Besides, the majority of the students considered the visit to the central laboratory and seeing how Brucellosis serologic tests are conducted to be quite educative and useful to accomplish the educational objectives (Table 3 ).

\section{Table 3: Frequency distribution of student's view on Brucellosis serology tests}




\begin{tabular}{|c|c|c|c|c|c|c|c|c|c|}
\hline \multirow{2}{*}{$\begin{array}{l}\text { strongly } \\
\text { disagree } \\
\mathrm{n} \\
\%\end{array}$} & \multicolumn{2}{|c|}{$\begin{array}{l}\text { somewhat } \\
\text { disagree }\end{array}$} & \multirow{2}{*}{$\begin{array}{l}\text { slightly } \\
\text { disagree } \\
\mathrm{n} \\
\%\end{array}$} & \multicolumn{2}{|c|}{ Undecided } & \multirow{2}{*}{$\begin{array}{l}\text { slightly } \\
\text { agree } \\
n \\
\%\end{array}$} & $\begin{array}{l}\text { somewhat } \\
\text { agree }\end{array}$ & \multirow{2}{*}{$\begin{array}{l}\text { strongly } \\
\text { agree } \\
n \\
\%\end{array}$} & \multirow[t]{2}{*}{ Item } \\
\hline & $\mathrm{n}$ & $\%$ & & $\mathrm{n}$ & $\%$ & & $\%$ & & \\
\hline $0(0)$ & $1(1)$ & & $3(3.1)$ & $3(3.1)$ & & $9(9.3)$ & $26(26.8)$ & $\begin{array}{l}55 \\
(56.7)\end{array}$ & $\begin{array}{l}\text { It was very } \\
\text { helpful and } \\
\text { instructive for } \\
\text { me to see how } \\
\text { a Wright } \\
\text { serology test to } \\
\text { diagnose } \\
\text { malaria is done } \\
\text { by a laboratory } \\
\text { expert. }\end{array}$ \\
\hline $0(0)$ & $0(0)$ & & $1(1)$ & $1(1)$ & & $\begin{array}{l}10 \\
(10.3)\end{array}$ & $26(26.8)$ & $\begin{array}{l}59 \\
(60.8)\end{array}$ & $\begin{array}{l}\text { The } \\
\text { observation } \\
\text { and } \\
\text { explanations of } \\
\text { the laboratory } \\
\text { expert on how } \\
\text { to dilute the test } \\
\text { tubes in wright } \\
\text { test were very } \\
\text { helpful and } \\
\text { instructive for } \\
\text { me. }\end{array}$ \\
\hline $0(0)$ & $1(1)$ & & $2(2.1)$ & $5(5.2)$ & & $8(8.2)$ & $27(27.8)$ & $\begin{array}{l}54 \\
(55.7)\end{array}$ & $\begin{array}{l}\text { It was very } \\
\text { useful and } \\
\text { instructive for } \\
\text { me to see the } \\
\text { positive wright } \\
\text { agglutination } \\
\text { and how to } \\
\text { read and report } \\
\text { it. }\end{array}$ \\
\hline $1(1)$ & $1(1)$ & & $4(4.1)$ & $5(5.2)$ & & $7(7.2)$ & $24(24.7)$ & $\begin{array}{l}55 \\
(56.7)\end{array}$ & $\begin{array}{l}\text { The transfer of } \\
\text { experiences } \\
\text { and } \\
\text { explanations of } \\
\text { the laboratory } \\
\text { expert and } \\
\text { instructor about } \\
2 \text { ME diagnostic } \\
\text { test and how to } \\
\text { distinguish } \\
\text { active } \\
\text { Brucellosis } \\
\text { from inactive } \\
\text { one was very } \\
\text { helpful and } \\
\text { instructive for } \\
\text { me. }\end{array}$ \\
\hline $0(0)$ & $1(1)$ & & $2(2.1)$ & $5(5.2)$ & & $\begin{array}{l}10 \\
(10.3)\end{array}$ & $23(23.7)$ & $\begin{array}{l}56 \\
(57.7)\end{array}$ & $\begin{array}{l}\text { The } \\
\text { explanation of }\end{array}$ \\
\hline
\end{tabular}


the laboratory expert and instructor about the effect of drug treatment on serological tests for Brucellosis was very helpful and instructive for me.

The percentage of total satisfaction from the visit was $92.61 \pm 11.87$ out of $100 \%$. Satisfaction rates for each of the abovementioned sections were also at a very good level (Table 4).

\section{Table 4: Satisfaction percentage of students visiting different parts of the city's health center in percentage}

\begin{tabular}{|lll|}
\hline Unit & Mean & SD \\
\hline Leishmaniasis & 93.38 & 11.80 \\
\hline Prevention of Rabies & 89.25 & 16.51 \\
\hline Brucellosis & 82.69 & 20.77 \\
\hline Total satisfaction & 92.61 & 11.87 \\
\hline
\end{tabular}

Table 5 indicates the mean and standard deviation of the scores on the seven-point Likert-scale for the three departments. According to these scores, the Leishmaniasis department got the highest score while the laboratory department got the lowest score. However, the average scores of the departments are pretty close (Table 5).

\section{Table 5: Mean and standard deviation of the visited unit's scores}

\begin{tabular}{|lll|}
\hline Unit & Mean \pm SD & Scores range \\
\hline Leishmaniasis & $0.50 \pm 6.72$ & $3.78-7$ \\
\hline Prevention of Rabies & $0.57 \pm 6.57$ & $3.56-7$ \\
\hline Brucellosis & $0.93 \pm 6.28$ & $2.60-7$ \\
\hline Total satisfaction & $0.51 \pm 6.53$ & $4.06-7$ \\
\hline
\end{tabular}

Comparison of the satisfaction certain from various departments among continuous and discontinuous bachelor's students based on the independent samples t-test indicated that the satisfaction of 


\section{Table 6: Results of Independent samples t-test to compare the satisfaction percentage between the two groups of students}

\begin{tabular}{|llll|}
\hline Unit & $\begin{array}{c}\text { Satisfaction percentage } \\
\text { Continuous } \\
\text { Mean } \pm \text { SD }\end{array}$ & $\begin{array}{l}\text { Satisfaction percentage } \\
\text { discontinuous } \\
\text { Mean } \pm \text { SD }\end{array}$ & P-value \\
\hline Leishmaniasis & $10.21 \pm 91.55$ & $13.00 \pm 95.10$ & 0.140 \\
\hline Prevention of rabies & $18.16 \pm 85.80$ & $14.24 \pm 92.50$ & 0.047 \\
\hline Laboratory & $22.50 \pm 90.80$ & $15.21 \pm 90.80$ & 0.001 \\
\hline Total satisfaction & $11.97 \pm 94.34$ & $11.97 \pm 94.34$ & 0.135 \\
\hline
\end{tabular}

Results of the Pearson coefficient indicated no significant relationship between students' satisfaction percentage and their average grade mark $(P>0.05)$. Besides, most of the students reported they preferred this type of learning over other topics of the course, specifically the case of tuberculosis disease.

\section{Discussion}

The present study was conducted aiming to determine the impact of visits to the operational departments of Gonbad-e Kavous healthcare center on public health students' satisfaction with course objective achievement. Generally, the results indicated that the students were highly satisfied with this type of learning. The highest reported satisfaction was associated with the department of CL. The reason for such satisfaction was seeing Leishmaniasis patients from proximity, getting familiar with the treatment procedure according to the type of the wound (systematic and local treatment, cryotherapy). In this department, the students had been divided into small groups to have the chance to see various Leishmaniasis wound and their respective treatments. Besides, students observed sample-taking from a wound suspected of CL, how to stain it (Giemsa staining), and observance of Leishmaniasis body particles with full description and explanation of the CL staff and learned about the aforementioned. One of the reasons could be that conventional learning in the traditional classroom was supplemented with the visit and the provision of a live learning environment increased students' learning. According to Edgar Dale's cone of learning experiences, object, direct, and first-hand results in increased and improved learning(11) . Besides, according to this learning experience cone, principles at the base of the cone were used as much as possible in teaching students, and signs and symbols (such as simple lectures) that were at the tip of the cone were used less (11). Results of Sathishkumar et al.'s study on freshman medical students aiming to impact of clinical visits on learning endocrine glands physiology course revealed that early presence of students in clinical visits increased their satisfaction. They believed that these visits increased their 
conventionally-gained knowledge, increased their memorization of the learning materials, improved their knowledge, and integrated their knowledge in this field. Most of the students believed that these visits made them more sensitive to patients and their needs (12). Results of Jefferson et al. indicated that field visits of students from Alzheimer's patients made the students develop a generally favorable attitude to these patients, and considered this type of education quite valuable and useful (13).

The following department with the highest satisfaction rate was the rabies control and prevention department. Still, satisfaction from this department was similar to satisfaction from CL. The reason could be that in this department, no animal-bitten patient was referred to the healthcare center during one of the student groups' visits, so they did not get the chance to observe how the serum was injected and how its dose was calculated. In this department, the students got familiar with how the wound was washed, injection protocols, the indications of rabies prevention serum injection, and how its dose was calculated from proximity along with comprehensive explanations from the department's employees. The possibility of a question and answer session was also available favorable which increased their use of vision and, therefore, improved learning. Education technology experts believe that $75 \%$ of the learning takes place through the sense of vision. Edgar Dale believes that using the learning experiences residing in the base of the cone results in $90 \%$ retention of the learning materials in the learner's mind (11).

Although the satisfaction with the central laboratory department for Wright, Wright Vidal, and 2ME tests performed was lower than the other departments, it was still pretty high. The reason could be students' tiredness since this department was visited at the final hours of the visit and after the departments of rabies prevention and control and CL. In this department, the teachers' prior arrangements and preparation of real Brucellosis patients to show the actual serum sample agglutination in various dilutions attracted the students' curiosity and attention and improved their satisfaction and learning. The method of preparing various dilutions of the triple Brucellosis made the students better familiar with laboratory interpretations and diagnosis protocols. Results of Taylor \& Mann's study indicated that two genetic consultants' trip to the family cancer center accompanying cancer patients in the stages of diagnosis, treatment, chemotherapy, radiotherapy, surgery, and aftercare increased their knowledge of cancer patient's diagnosis and treatment and improved their sense of responsibility and empathy regarding these patients. On this trip, they visited gynecology, oncology, and gastroenterology specialists and surgeons in various wards of Royal Melbourne Hospital and became closely familiarized with cancer patients' treatment procedures. These two genetic consultants reported that their trip had a positive impact on their better understanding of cancer patients(14) .

Results indicated that general satisfaction of discontinuous bachelor's students was generally higher compared to continuous bachelor's students, and this satisfaction was significantly higher in discontinuous students in Brucellosis and rabies control and prevention departments. This finding could be since discontinuous bachelor's students - who had associate's degrees- had gotten acquainted with these materials in their previous courses but had had no real contact with these topics. Of course, the satisfaction of continuous students was expected to be higher than discontinuous students since they had no former contact with the field of health before the semester when this course was delivered, i.e. the fifth semester. Besides, results indicated no significant correlation between students' GPA and satisfaction, which means 
the visit had the same level of attraction for students with various GPAs and had been received by weaker and stronger students in the same way.

Having a cross-sectional nature, the use of the questionnaire, and the limitation of visiting three separate departments in one day are among the limitations of the present study that must be considered if results are to be generalized. Besides, the distance between Gonbad-e Kavous and Gorgan (100km) and its resulting tiredness could have impacted students' satisfaction.

\section{Conclusion}

To sum up, the results of these visits revealed that presence at the patient's bedside and community-based learning resulted in better achievement of educational objectives since they provide actual, direct, and firsthand experiences. Besides, students reported high satisfaction with this type of learning. Hence, the continuation of this type of learning could be effective and useful for other classes of public health students. Therefore, such visits and scientific field trips are recommended to be carried on with other public health students. Hence, further such visits are suggested and recommended for other public health students (both programs) in the future after eliminating the limitation of time constraints in visits.

\section{Abbreviations}

$\mathrm{CL}$; coetaneous Leishmaniasis

\section{Declarations}

\section{Acknowledgements}

The author would like to Gonbad-e-Kavus health authorities for kindly providing visit of departments.

\section{Author contribution}

All aspects of the study were conducted by AC.

\section{Funding}

Golestan University of Medical Sciences.

\section{Availability of data and materials}

Data are available upon request to the author.

\section{Ethics approval and consent to participate}

Formal ethical approval was obtained from the Golestan University of Medical Sciences ethics committee ID ( IR.GOUMS.REC.1396.236). All methods were carried out in accordance with relevant guidelines and regulations. Besides, informed consent was obtained from all participants. 


\section{Consent for publication}

Not applicable.

\section{Competing interests}

The author declares that they have no competing interest.

\section{References}

1. Raeisi A, Zahraei M, Sorosh NajafAbadi M. Comprehensive guideline of communicable diseases surveillance system for family physician. Tehran: Andishmand. 2012.

2. Shirjang A, Alizadeh M, Mortazavi F, Asghari Jafarabadi M, Jeddi A. Relevance of public health BSc curriculum to job requirements and health system expectations: Views of graduates on courses syllabi and content. Iranian journal of medical education. 2013;12(10):768-77.

3. Razmara Ferezghi H, Razmara Ferezghi M, Javadinia S. Health Sector Evolution and Medical Education Necessity of providing education supplement. Strides Dev Med Educ. 2016;12(5):e58529.

4. Public Health BSc Curriculum. Ministry of Health 2016. Available from: http://sph.umsha.ac.ir/index.aspx?fkeyid=\&siteid=18\&pageid=5220.

5. Öcek ZA, ÇiÇeklioğlu M, Gürsoy ŞT, Aksu F, Soyer MT, Hassoy H, et al. Public health education in Ege University Medical Faculty: developing a community-oriented model. Medical teacher. 2008;30(910):e180-e8.

6. Khan I, Fareed A. Perceptions of students and faculty about conventional learning and communityoriented medical education. Journal of the College of Physicians and Surgeons-pakistan: JCPSP. 2003;13(2):82-5.

7. Klegeris A, Hurren $\mathrm{H}$. Impact of problem-based learning in a large classroom setting: student perception and problem-solving skills. Advances in physiology education. 2011;35(4):408-15.

8. Saif AA. Modern educational psychology. 6th ed2009. 213-8 p.

9. Malekpour Afshar R, Noori Hekmat S, Dehnavieh R, Balochi M. Transformational Packages in Medical Sciences Education; the Importance of Roadmap. Strides in Development of Medical Education. 2019;16(1).

10. Jorjani O, Mirkarimi K, Charkazi A, Shahamat Y, Mehrbakhsh Z, Bagheri A. The epidemiology of cutaneous leishmaniasis in Golestan Province, Iran: A cross-sectional study of 8-years. Parasite Epidemiol Control [Internet]. 2019 May [cited 2019 Jan 25]; 5: e00099.

11. Dale E. Audiovisual methods in teaching. 1969.

12. Sathishkumar S, Thomas N, Tharion E, Neelakantan N, Vyas R. Attitude of medical students towards early clinical exposure in learning endocrine physiology. BMC Medical Education. 2007;7(1):1-7.

13. Jefferson AL, Cantwell NG, Byerly LK, Morhardt D. Medical student education program in Alzheimer's disease: The PAIRS Program. BMC medical education. 2012;12(1):1-8. 
14. Taylor J, Mann K, editors. Observation of the cancer patient journey: a learning curve for Genetic Counsellors. Hereditary Cancer in Clinical Practice; 2012: BioMed Central. 